\title{
Aeschynomene evenia, a Model Plant for Studying the Molecular Genetics of the Nod-Independent Rhizobium-Legume Symbiosis
}

\author{
Jean-François Arrighi, ${ }^{1}$ Fabienne Cartieaux, ${ }^{1}$ Spencer C. Brown, ${ }^{2}$ Marguerite Rodier-Goud, ${ }^{3}$ \\ Marc Boursot, ${ }^{1}$ Joel Fardoux, ${ }^{1}$ Delphine Patrel, ${ }^{1}$ Djamel Gully, ${ }^{1}$ Sandrine Fabre, ${ }^{1}$ Clémence Chaintreuil, ${ }^{1}$ \\ and Eric Giraud ${ }^{1}$
}

${ }^{1}$ IRD, Laboratoire des Symbioses Tropicales et Méditerranéennes, UMR IRD/SupAgro/INRA/UM2/CIRAD, Campus International de Baillarguet, TA A-82/J, 34398 Montpellier Cedex 5, France; ${ }^{2} \mathrm{CNRS}$, IBiSA imagerie Gif, Institut des Sciences du Végétal, UPR 2355, 23/24, avenue de la Terrasse, 91198 Gif-sur-Yvette, France; ${ }^{3}$ CIRAD, Laboratoire de Cytogénétique Moléculaire, UMR AGAP, TA-A 108/03, 34398 Montpellier Cedex 5, France

Submitted 22 February 2012. Accepted 22 March 2012.

Research on the nitrogen-fixing symbiosis has been focused, thus far, on two model legumes, Medicago truncatula and Lotus japonicus, which use a sophisticated infection process involving infection thread formation. However, in $25 \%$ of the legumes, the bacterial entry occurs more simply in an intercellular fashion. Among them, some Aeschynomene spp. are nodulated by photosynthetic Bradyrhizobium spp. that do not produce Nod factors. This interaction is believed to represent a living testimony of the ancestral state of the rhizobium-legume symbiosis. To decipher the mechanisms of this Nod-independent process, we propose Aeschynomene evenia as a model legume because it presents all the characteristics required for genetic and molecular analysis. It is a short-perennial and autogamous species, with a diploid and relatively small genome $(2 \mathrm{n}=20 ; 460 \mathrm{Mb} / 1 \mathrm{C})$. A. evenia 'IRFL6945' is nodulated by the well-characterized photosynthetic Bradyrhizobium sp. strain ORS278 and is efficiently transformed by Agrobacterium rhizogenes. Aeschynomene evenia is genetically homozygous but polymorphic accessions were found. A manual hybridization procedure has been set up, allowing directed crosses. Therefore, it should be relatively straightforward to unravel the molecular determinants of the Nod-independent process in A. evenia. This should shed new light on the evolution of rhizobium-legume symbiosis and could have important agronomic implications.

Due to their ability to interact symbiotically with nitrogenfixing bacteria collectively called rhizobium, legumes are major contributors to the global nitrogen cycle and, thus, they have a tremendous ecological and agronomic importance. This interaction results in the formation of a new organ, the nodule, where the bacteria fix nitrogen to the benefit of the plant and, in exchange, receive carbon substrates. Dur-

Corresponding author: J.-F. Arrighi; Telephone: +33 (0) 4675937 83; Fax: +33 (0) 4675938 02; E-mail: jean-francois.arrighi@ird.fr

* The $\boldsymbol{e}$-Xtra logo stands for "electronic extra" and indicates that seven supplementary tables and one supplementary figure are published online and that Figures 1 through 6 appear in color online. ing these last two decades, intensive international research, mainly conducted on two symbiotic models (Lotus japonicusMesorhizobium loti and Medicago truncatula-Sinorhizobium meliloti), has led to a better understanding of the molecular mechanisms of this interaction. In both systems, the early steps of the symbiosis are extremely conserved. This involves the perception by the plant of bacterial signal molecules, the "Nod factors"(NF), that trigger two distinct, spatially and temporally coordinated programs: bacterial infection and nodule organogenesis. The infection process is particularly sophisticated: it occurs via root hairs thanks to the formation of an infection thread guiding the bacteria to the emerging nodule primordium that is formed concomitantly by mitotic reactivation of some cortical cells. A mutagenesis screen in these two model legumes has led to the identification of numerous components of the NF-signaling pathway (Jones et al. 2007; Madsen et al. 2010; Oldroyd et al. 2011). Interestingly, some of these components are also recruited for other endosymbioses such as mycorrhization or nodulation of actinorhizal plants by Frankia strains (Gherbi et al. 2008; Parniske 2008). This led to the proposal that plants developing endosymbioses share common signal transduction mechanisms (Markmann and Parniske 2009).

However, the study of these two model plants that both belong to the Galegoid clade remains restricted, and they are far from representing the diversity of the symbiotic mechanisms used by legumes to interact with rhizobium (MassonBoivin et al. 2009; Sprent and James 2008). Indeed, in some tropical and Mediterranean legumes, including Arachis hypogaea and Lupinus albus that are major legume crops in these world regions, an alternative mode of infection has been described where the entry of the bacteria occurs intercellularly between epidermal cells (Chandler 1978; Chandler et al. 1982; Gonzales-Sama et al. 2004). In addition to the absence of infection thread formation, there is no distant induction of a primordium. In fact, the nodule originates from the successive divisions of only one or a few infected cortical cells, also called founder cells. The intercellular infection pathway is considered to be the ancient mode of invasion of plant tissues; it is supposed to occur in $25 \%$ of legumes species belonging essentially to the Dalbergioid or Genistoid clades (Sprent 2007, 2008). Most surprisingly, in some Aeschy- 
nomene spp. that are phylogenetically related to the genus Arachis, a Nod-independent symbiotic process has been also described where the symbionts (i.e., photosynthetic Bradyrhizobium strains) are able to form nodules in the absence of NF synthesis using an infection process similar to the one described in Arachis hypogaea (Bonaldi et al. 2011). These data indicate that an alternative signaling pathway is possible to trigger the development of efficient nitrogen-fixing nodules. The identification of the specific determinants of this new symbiotic process will necessitate the development of an adequate legume model (i.e., a species that does not require NF for symbiosis, that is diploid with a small genome, that is easy to manipulate and genetically transform, and which possesses a short generation time).

At present, the Nod-independent symbiotic process has been described only in some Aeschynomene spp. The Aeschynomene genus belongs to the Dalbergioid clade and includes approximately 150 species, of which 22, that are semiaquatic, were described to be nodulated on roots and stems by photosynthetic Bradyrhizobium strains (Giraud et al. 2000). Among these, two groups could be distinguished that differ in their requirement for NF to initiate symbiosis. One group of 5 species, including A. afraspera and A. nilotica, is nodulated only by nod-gene-containing Bradyrhizobium strains such as ORS285 strain (Chaintreuil et al. 2001), whereas the second group, with 11 species, is nodulated by photosynthetic Bradyrhizobium strains that lack the nod genes (such as BTAi1 or ORS278) (Giraud et al. 2007). A. indica belongs to this latter group and corresponds to the species that has been used thus far to progress in understanding the Nodindependent symbiotic process, essentially because it is a convenient host plant for photosynthetic Bradyrhizobium strains lacking nod genes and because genetic resources were available (Bonaldi et al. 2010a and b, 2011). Recently, an efficient root-transformation protocol using Agrobacterium rhizogenes has been developed, allowing reverse genetic approaches (Bonaldi et al. 2010a). However, A. indica is a polyploid species (Bielig 1997), excluding the possibility to develop mutagenesis on this plant in order to identify the specific Nod-independent symbiotic genes.

In this study, we explore the diversity of 11 Aeschynomene spp. using a Nod-independent symbiotic process to identify an appropriate diploid species for forward genetic approaches. The A. evenia species appears to gather all the required criteria to constitute a new bona fide "model" legume for studying the molecular mechanisms of the "nonconventional" rhizobiumlegume symbiosis.

\section{RESULTS}

A. evenia emerges as the most promising

Nod-independent Aeschynomene sp.

Among the 11 Aeschynomene spp. using a Nod-independent symbiotic process, three species (A. evenia, A. sensitiva, and A. denticulata) were previously described as diploid, with $2 \mathrm{n}=$ 20 chromosomes, and 1 species (A. indica) as tetraploid, with $2 n=40$ chromosomes (Bielig 1997). To get more insight on the ploidy level of the other species, their 2C DNA content, estimated by flow cytometry, was compared with those of the reference species (Table 1). From these data, it could be predicted that 7 of the 11 Aeschynomene spp. examined are diploid (Table 1).

Among them, some species were discarded from further study because of major inconveniences such as biennial flowering (A. sensitiva), low seed production (A. tambacoundensis, personal observation), or too-limited genomic resources available in germplasm collections (A. tambacoundensis and A. ciliata). In contrast, the $A$. evenia species, which possesses the second smallest genome $(0.95 \mathrm{pg} / 2 \mathrm{C})$, gathers several features that make it particularly promising to constitute an appropriate model legume. i) Two varieties have been described, A. evenia var. evenia and var. serrulata, indicating intraspecific polymorphism, which is an important criterion for the identification of two polymorphic parents required for the generation of a genetic map. ii) Many accessions from different areas of the world are available. iii) It is the species most closely related to A. indica (C. Chaintreuil, unpublished data), for which most of the data on the Nod-independent symbiotic process were obtained. iv) Flowering and seed production occur throughout the year (Vendramini et al. 2010). Furthermore, for this species, commonly named "Shrubby Joint vetch", one commercial cultivar ('IRFL6945') is used in North American agriculture as a forage legume (Kretschmer et al. 1994, 1997).

\section{Genome characteristics.}

Compared with other agriculturally and scientifically important legumes (Fig. 1A), it is clear that A. evenia has a relatively small genome- $0.95 \mathrm{pg}$ for $2 \mathrm{C}$ corresponds to a monoploid genome size of approximately $460 \mathrm{Mb}$ - similar to those of the two model legumes M. truncatula and L. japonicus (520 and $470 \mathrm{Mb}$, respectively).

To get a better insight into the genome structure of $A$. evenia, we conducted cytogenetic analysis (Fig. 1B). Twenty homogeneous-sized chromosomes were counted, which is consistent with previously published data (Bielig 1997). Using in situ hy-

Table 1. Characteristics of the Nod-independent Aeschynomene spp.

\begin{tabular}{|c|c|c|c|c|c|c|c|}
\hline Species & $\begin{array}{c}\text { Chromosome } \\
\text { number }^{v}\end{array}$ & $\begin{array}{c}2 \mathrm{C} \text { DNA } \\
\text { content (pg) }\end{array}$ & $\begin{array}{l}\text { Ploidy } \\
\text { level }^{w}\end{array}$ & Development $^{x}$ & Distribution $^{x}$ & Varieties $^{\mathbf{y}}$ & $\begin{array}{c}\text { Number of accessions } \\
\text { available in seed banks }\end{array}$ \\
\hline Aeschynomene ciliata & $\ldots$ & $1.08 \pm 0.02$ & $2 x$ & Perennial & Central-South America & 1 & $3(a)+0(b)+0(c)+2(d)$ \\
\hline A. deamii & $\ldots$ & $1.93 \pm 0.05$ & $4 x$ & Perennial & Central-South America & 1 & $2(a)+0(b)+0(c)+2(d)$ \\
\hline A. denticulata & 20 & $1.29 \pm 0.03$ & $2 x$ & Perennial & South America & 1 & $2(a)+0(b)+0(c)+9(d)$ \\
\hline A. evenia & 20 & $0.95 \pm 0.03$ & $2 x$ & Short perennial & Pan-American/Africa & 2 & $40(a)+1(b)+0(c)+12(d)$ \\
\hline A. indica & 40 & $1.71 \pm 0.04$ & $4 x$ & Annual & Pan-tropical & 1 & $51(a)+6(b)+6(c)+22(d)$ \\
\hline A. pratensis & $\ldots$ & $3.14 \pm 0.05$ & $6 x$ & Perennial & Central-South America & 2 & $8(a)+0(b)+0(c)+0(d)$ \\
\hline A. rudis & $\ldots$ & $1.03 \pm 0.01$ & $2 x$ & Short perennial & Pan-American & 1 & $28(a)+0(b)+0(c)+5(d)$ \\
\hline A. scabra & $\ldots$ & $1.03 \pm 0.03$ & $2 x$ & Perennial & Central-South America & 1 & $15(a)+1(b)+1(c)+6(d)$ \\
\hline A. sensitiva & 20 & $1.37 \pm 0.06$ & $2 x$ & Perennial & Central-South America/Africa & 3 & $47(a)+1(b)+5(c)+13(d)$ \\
\hline A. tambacoundensis & $\ldots$ & $0.67 \pm 0.03$ & $2 x$ & Annual & West Africa & 1 & $0(a)+0(b)+0(c)+0(d)$ \\
\hline A. virginica & $\ldots$ & $2.08 \pm 0.02$ & $4 x$ & Annual & Pan-American & 1 & $1(a)+1(b)+0(c)+0(d)$ \\
\hline
\end{tabular}

${ }^{\mathrm{v}}$ Index to Plant Chromosome Numbers, Bairiganjan and Patnaik (1989), and Bielig (1997).

${ }^{\mathrm{w}}$ In bold, those determined previously; in italics, those predicted from genome size.

${ }^{x}$ Data from Tropicos and the International Legume Database \& Information Services.

${ }^{y}$ Number of varieties, from Rudd (1955) and Kretschmer and associates (1997).

${ }^{\mathrm{z}}$ Lowercase letters: a, Centro International de Agricultura Tropical; b, United States Department of Agriculture; c, Kew Gardens seed bank; and d, Australian

Plant Genetic Resource Information Service. 
bridization, we could detect one pair of 5S rDNA loci with a proximal localization and two pairs of $45 \mathrm{~S}$ rDNA loci with contrasted signal intensities that were both located in secondary constrictions of satellite chromosomes. All three detected pairs of rDNA loci mapped on different chromosomes, permitting their unambiguous identification. Taken together, these data indicate that A. evenia has characteristics which would facilitate genomic and genetic approaches.

Plant development and culture.

A. evenia is a short-lived perennial that can reach a height of approximately $2 \mathrm{~m}$. The generation time observed for IRFL6945 was short (10 weeks). Flowering was induced in plants grown under full ambient light in the greenhouse in short days (i.e., a daylight length less than 12 h). Once set, flowering was maintained during the rest of the year with a continuous seed production, allowing the collection of more than 6,000 seeds from a single plant during its life time (Fig. 2A). The plants have an erect and branching habit and become shrubby when older (Fig. 2B). Leaves are bipinnate and flowers have yellow petals with reddish striations. They are carried on peduncles radiating from axils along the branches (Fig. 2C). Fertilization and seed setting occurred without manipulations of the flowers. After pollination, a pod, generally comprising five to eight segments containing the seeds, developed and arrived at maturity in 3 weeks. Seeds are brownish, approximately $2 \mathrm{~mm}$ long and $1.5 \mathrm{~mm}$ wide.

Scarification with concentrated sulfuric acid allowed us to obtain an almost $100 \%$ germination rate, except for very freshly harvested seeds. In this latter case, additional manual removal
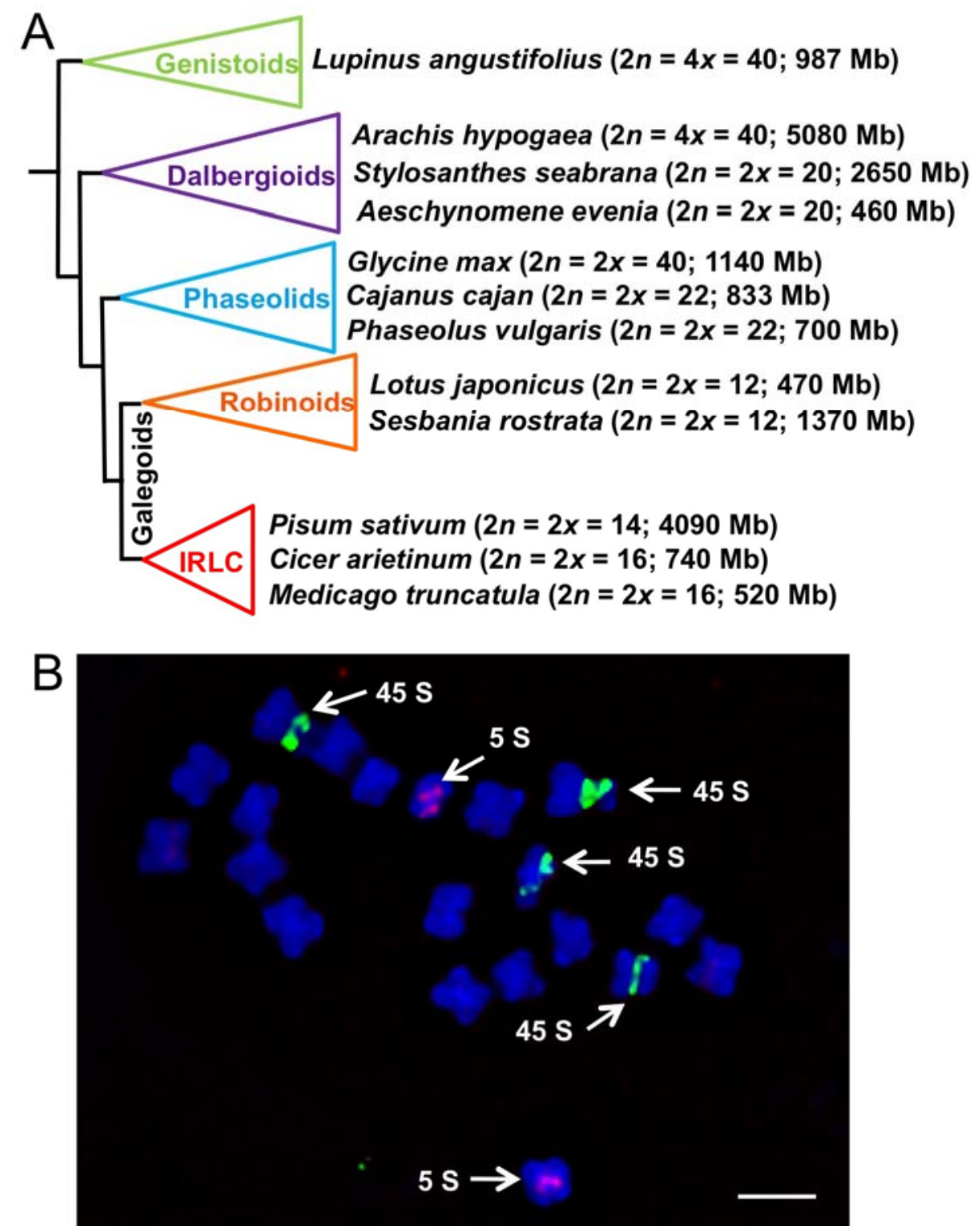

Fig. 1. Genome characteristics. A, Comparison of the Aeschynomene evenia genome with those of other legume species belonging to the Papilionoid family. The tree is a simplified phylogeny with triangles representing the major clades and the two subclades of the Galegoids: the Robinioids and the plastid DNA inverted repeat-lacking clade (IRLC). Notable species are indicated with their chromosome number and genome size (monoploid $\mathrm{C}$ value expressed in $\mathrm{Mb}$ ) between parentheses. Figure adapted from Bertioli and associates (2009). Genome size for species other than A. evenia are taken from Arumuganathan and Earle (1991), Marie and Brown (1993), Blondon and associates (1994), Temsch and Greilhuber (2000), Naganowska and associates (2003), Chandra and Kaushal (2009), and Varshney and associates (2012). All conversions were recalculated using $1 \mathrm{pg}$ DNA $=978 \mathrm{Mb}$. Chromosome counts come from the Index to Plant Chromosome Numbers. B, Somatic metaphase of A. evenia after double fluorescent in situ hybridization. The chromosomes were counterstained with 4',6-diamidino-2-phenylindole (blue), the probe for 18S-25S rDNA was detected by fluoresceine isothiocyanate (yellow-green), and the probe for $5 \mathrm{~S}$ rDNA by rhodamine (red). Scale bar $=2 \mu \mathrm{m}$. 
of the hard seed coat and the translucid gain surrounding the seedling could alleviate dormancy. Seeds kept at $4^{\circ} \mathrm{C}$ for at least 4 years still germinated with high frequency. Young plants were small enough to be conveniently grown in vitro for several weeks in tubes containing liquid medium (Fig. 2D). Plants could also be cultured in high density (100 plants per square meter) in the greenhouse, with flowering occurring when still under $0.5 \mathrm{~m}$ height. Multiplication from sections was tested and revealed that individual plants could be easily propagated with a $100 \%$-effective rooting in only 5 days.

\section{Symbiotic properties.}

We examined the ability of $A$. evenia to be nodulated by the commonly used laboratory strains of photosynthetic Bradyrhizobium (ORS278, BTAi1, and ORS285). The three strains were able to induce nitrogen-fixing nodules. However, they differed in their symbiotic efficiency, as revealed by plant growth and nodulation, the most efficient being strain ORS278 (Supplementary Fig. S1; Supplementary Table S1). The impact of symbiosis on growth of the plant was rapid and very high (Fig. 2D). This strong response could constitute a very interesting aspect to easily discriminate bacterial and plant mutants affected in symbiosis.

Using a green fluorescent protein (GFP)-tagged strain (ORS285 nnodB::GFP) that was previously shown to nodulate the closely related $A$. indica similarly to ORS278 (Bonaldi et al. 2011), we analyzed the infection process of $A$. evenia by confocal microscopy. In the hours following inoculation, we observed a strong proliferation of the bacteria, specifically at the surface of the axillary root hairs surrounding the lateral roots (Fig. 3A, B, and F). They then penetrated between the hairs and progressed intracellularly in the root cortex, most probably, as described for $A$. indica, by successive collapses of the initially infected cells (Fig. $3 \mathrm{H}$ ) (Bonaldi et al. 2011). As soon as 2 days postinoculation (dpi), some deeper infected cortical cells started to divide, giving rise to the nodule primordium (Fig. 3C and $\mathrm{G}$ ). The nodules then rapidly grew by successive division of these founder cells (Fig. 3D, E, H, I, and J). Between 5 and 6 dpi, a drastic change of the bacterial shape was observed as these became perfectly spherical (Fig. 3K and L). The nitrogenase activity could be detected from this stage (data not shown). Therefore, the process of infection and the kinetics of nodule organogenesis appeared very similar to that described previously in A. indica (Bonaldi et al. 2011).

\section{Transformation with Agrobacterium rhizogenes.}

The capacity to induce transgenic roots on A. evenia with Agrobacterium rhizogenes was investigated using the transformation procedure developed for the closely related $A$. indica (Bonaldi et al. 2010a). For this, direct application of Agrobacterium rhizogenes ARqua1 (Quandt et al. 1993) on freshly sectioned radicles was performed. Inoculated seedlings were placed at $20^{\circ} \mathrm{C}$ in obscurity for 1 week to optimize the transformation frequency formation and then put back in normal culture conditions to facilitate root development. Using the pHKN29 binary vector carrying the CaMV35S::GFP construct, we found that $57 \%$ of the composite plants had developed at least one green-fluorescent root at $21 \mathrm{dpi}$ (Fig. 4A and B; Table 2).

ARqual-transformed root systems were subsequently inoculated with Bradyrhizobium sp. strain ORS278. At 14 dpi, we observed that $87 \%$ of the transformed roots were nodulated (Fig. 4C and D) (Table 2). The average number of nodules on GFP-positive roots was comparable with that for control roots (approximately eight nodules per plant) (Table 2). No obvious phenotypic difference was found between green-fluorescent nodules and wild-type ones. In particular, both displayed the characteristic pink color of leghemoglobin, suggesting that they were functional. This was confirmed by an acetylene reduction assay (ARA) test revealing similar nitrogen-fixing activity of both types of nodules (Table 2). The expression pattern of the Cauliflower mosaic virus (CaMV) $35 S$ promoter in transgenic roots and nodules was investigated using a $35 \mathrm{~S}-\beta$ glucuronidase (GUS) intron marker construct. A GUS expression was clearly visible in the cortex and vascular tissues of the root zone susceptible for infection and also in nodules, thus reflecting the expression profile observed for A. indica (Fig. 4E and F) (Bonaldi et al. 2010a).

Together, these data demonstrate that the hairy root system using the Agrobacterium rhizogenes-mediated transformation can be successfully applied to A. evenia.
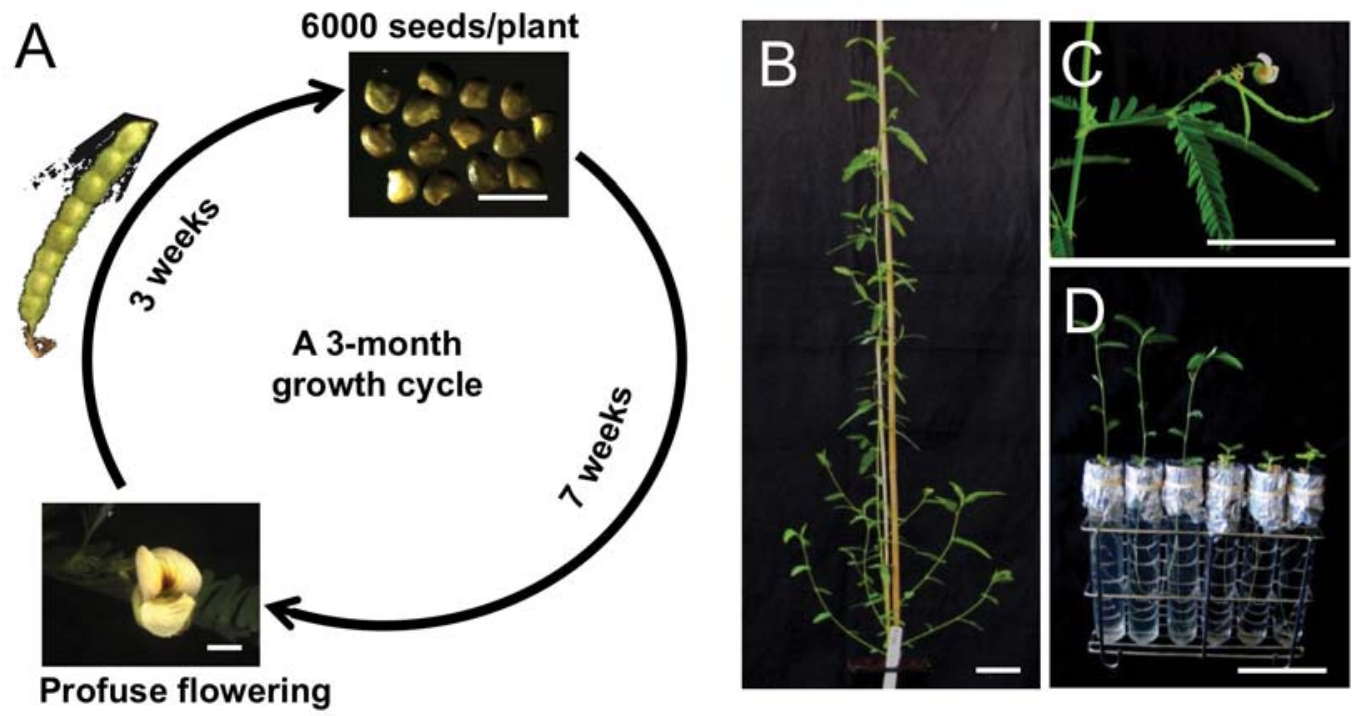

Fig. 2. Plant growth characteristics. A, Growth cycle showing a generation time seed-to-seed of 3 months. After the onset of flowering, the plant can produce more than 6,000 seeds over a period of 9 months. B, Two-month-old plant grown in pot showing an erect and branching habit. C, Zoom on a lateral flowering axis. D, Plants (17 days old) grown in vitro in nitrogen-free buffered nodulation medium (Bonaldi et al. 2011). On the left: plants inoculated with Bradyrhizobium sp. strain ORS278 (10 days postinoculation). On the right: control without inoculation. Scale bars $=4 \mathrm{~mm}(\mathrm{~A})$ and $6 \mathrm{~cm}(\mathrm{~B}, \mathrm{C}$, and D). 
Phenotypic and genetic polymorphism.

In order to investigate the diversity encountered in A. evenia, we selected a set of 22 accessions representative of the two varieties (evenia and serrulata) and originating from regions of the world where this species naturally grows.

First, the analysis of a number of morphological traits enabled us to assign each accession undoubtedly to one of the two described varieties (Rudd 1955). Hence, the variety evenia is characterized by glabrate stems, tender-green leaves with leaflets predominantly entire, flowers with an elliptic standard petal, and pods that are 10 to 14 articulate (Fig. 5A). The variety serrulata, including line IRFL6945, is distinctive in that the stems are covered with conspicuous glandular trichomes (Fig. 5A). Leaves are dark green and smaller, with leaflets consistently serrulate and ciliate. Flowers are recognizable by their obovate standard petal and much variation was found in their size. Pods are smaller, with only five to eight segments, but seeds are similar in size and shape (Figs. 2A and 5A).

Genetic diversity was examined using randomly amplified polymorphic DNA (RAPD) and simple-sequence repeat (SSR) markers. These latter were obtained from expressed sequence tag (EST) sequences available for the closely related $A$. indica and successfully amplified in A. evenia (F. Cartieaux, unpublished data). Most markers displayed a distinctive profile for the varieties serrulata and evenia but polymorphism was also easily found within each variety (Fig. 5B).

In order to identify two polymorphic parents with compatible flowering time and similar symbiotic efficiency, for all these accessions we examined their nodulation properties using strain ORS278 and scored their flowering time in short days. At $15 \mathrm{dpi}$, most accessions had developed a number of nodules, ranging from 8 to 12 per plant, which was comparable with that found for line IRFL6945 $(9.5 \pm 3$ nodules per plant). Concerning the second aspect, we found that more than half the accessions were early flowering ( 5 to 10 weeks).

Overall, these data indicate that line IRFL6945 and several other accessions present favorable similar characteristics (good nodulation efficiency and early flowering) and, at the same time, phenotypic and molecular polymorphisms necessary for a mapping approach.
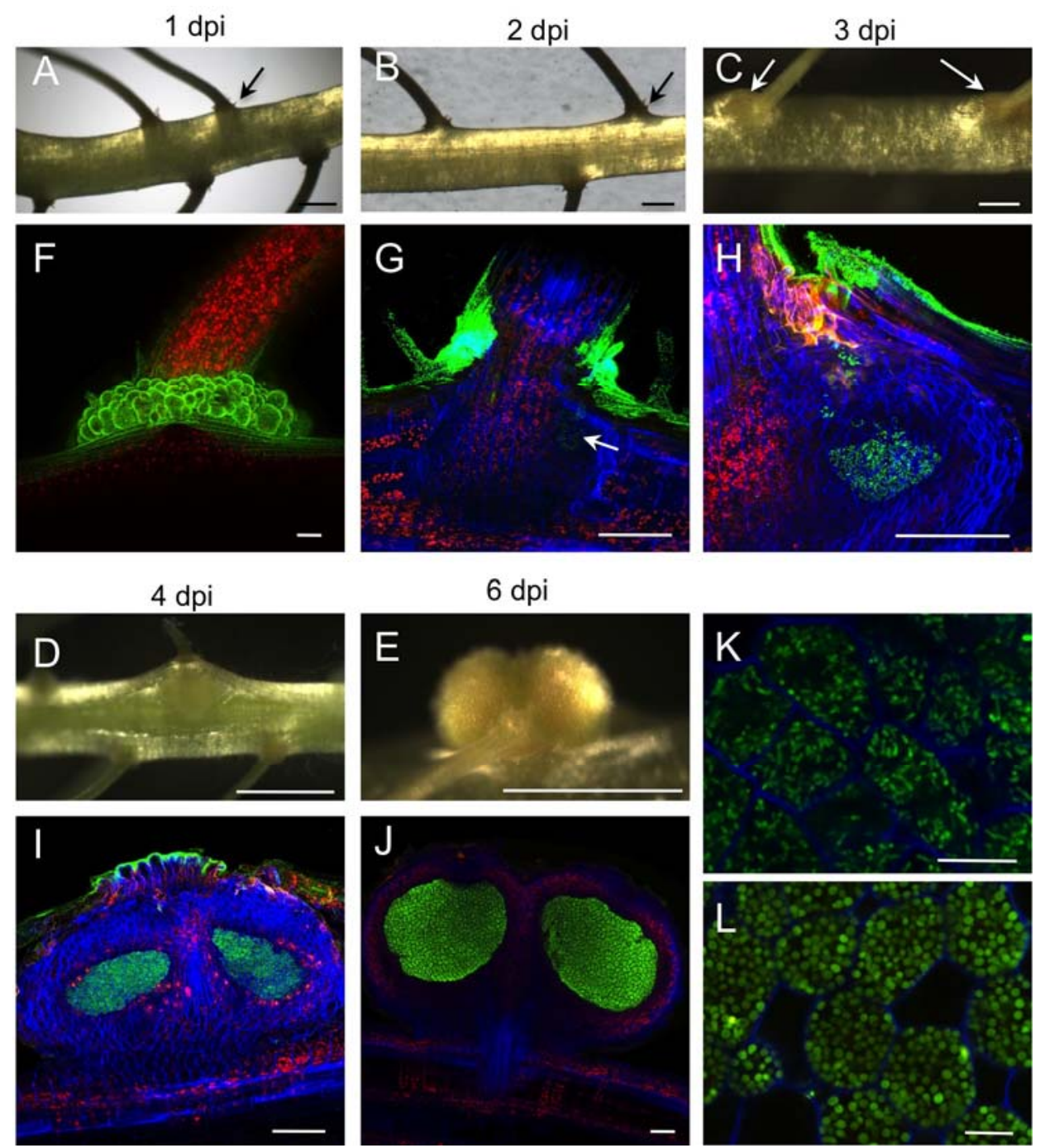

Fig. 3. Infection and nodule formation. A to $\mathbf{E}$, Bright-field micrographs of the root system at different time points after inoculation with Bradyrhizobium sp. strain ORS285 $\Delta$ nodB-green fluorescent protein $(G F P)$. Note the presence of $\mathbf{A}$ and $\mathbf{B}$, axillary hairs surrounding the lateral roots (dark arrows) and $\mathbf{C}$, first bumps that emerge at the level of lateral roots at 3 days postinoculation (dpi) (white arrows). D and $\mathbf{E}$, Development of the nodule at 4 and 6 dpi. $\mathbf{F}$ to $\mathbf{J}$, Confocal microscopy images showing bacterial infection and nodule development. F, Higher magnification of A, showing the proliferation of the bacteria at the surface of the axillary hairs. G, Some cortical cells are infected intracellularly (white arrows). H, General overview showing the progression of the bacteria inside the lateral root. I and $\mathbf{J}$, Cross-section of young nodules at 4 and $6 \mathrm{dpi}$, respectively. $\mathbf{K}$ and $\mathbf{L}$, Magnification of infected cortical cells of I and J, respectively, showing the conformational change of bacteria that occurs between 4 and 6 dpi. Bacteria appear in green (GFP), cell wall in blue (Calcofluor), and chloroplasts in red (autofluorescence). Scale bars $=1 \mathrm{~mm}$ (A to E), $100 \mu \mathrm{m}$ (F to J), and $10 \mu \mathrm{m}$ (K and L). 
Autogamy and cross pollination.

During the genotyping analysis, whatever the SSR markers used (12), in almost all cases, only one polymerase chain reaction (PCR) band was detected for all the plants tested (Supplementary Table S4), suggesting that these plants were predominantly homozygous and that $A$. evenia is probably a selfing species.

In order to check that autogamy is favored, and also with the aim to set up a crossing protocol, a study of flower development was carried out on the IRLF6945 line. The following events could be distinguished: the day before flower opening (d-1), petals emerged from the calyx of the buds; at day 0 , flowers continued to develop and open synchronously in the morning; and, the day after $(\mathrm{d}+1)$, the flowers were closed back and petals withered; then, at $\mathrm{d}+2$, young developing pods became visible (Fig. 6A). Macroscopic observations at day 0 (Fig. 6B) revealed that the pistil first elongates (approximately 8:00 a.m.), followed by one stamen. Then, anthesis occurs (approximately 9:00 a.m.) prior to flower opening (approximately 10:00 a.m.) in such a fashion that anther dehiscence faces the stigma on which pollen is deposited. The other anthers succes-

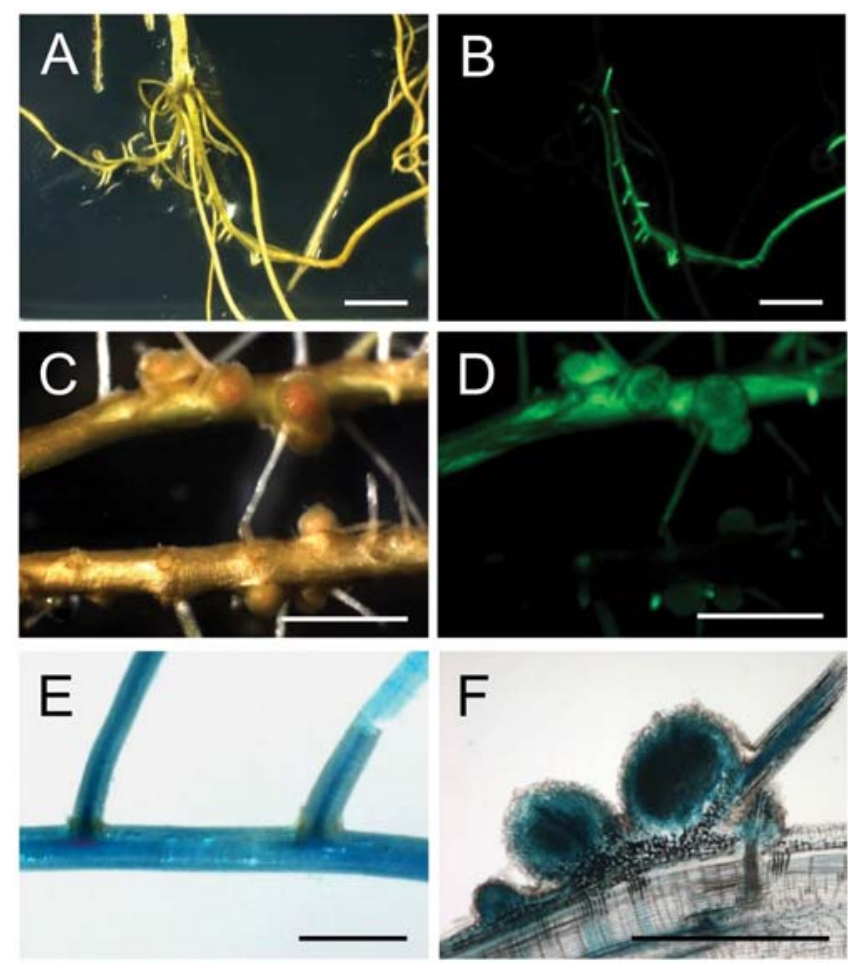

Fig. 4. Agrobacterium rhizogenes-mediated transformation. Composite roots observed under either $\mathbf{A}$, white or $\mathbf{B}$, blue light for epifluorescence of green fluorescent protein (GFP) 21 days after transformation with Agrobacterium rhizogenes ARqua1 expressing the $\mathrm{pCaMV35S::GFP}$ construct. Nodule development on composite roots showing differential epifluorescence levels under $\mathbf{C}$, white and $\mathbf{D}$, blue light 21 days postinoculation with Bradyrhizobium sp. strain ORS278. $\beta$-Glucuronidase staining in transformed roots and nodules expressing the pCaMV35S::gusA-int construct in $\mathbf{E}$, the root zone susceptible for infection before inoculation and $\mathbf{F}$, young nodules elicited with ORS 278 . Scale bars $=1 \mathrm{~cm}$. sively elongate and stamens dehisce and finally form a crown surrounding the stigma (from 10:00 a.m. to 5:00 p.m.). During flower opening, sexual pieces remain mainly hidden behind the sepals (Fig. 6B). These observations revealed a process of cleistogamy, as already described for M. truncatula and Arachis hypogaea, indicating that $A$. evenia is likely to be self pollinated.

This knowledge of flower development was used to perform artificial hybridization between polymorphic accessions belonging either to the two varieties serrulata and evenia or to the same variety (Supplementary Table S5). In short, at day 0, recipient flowers were emasculated before anthesis and were pollinated as soon as the donor flower was opened (approximately $2 \mathrm{~h}$ later). This simple protocol gave a $95 \%$ success rate of pod development whatever the crossing tested. The seeds obtained readily germinated and gave healthy $\mathrm{F} 1$ plants whose heterozygosis was checked using SSR markers (Fig. 6C). Depending on the crossing, these hybrid plants displayed morphological characteristics of one or the other of the two parents. It is noteworthy that all flourished and developed seed-containing pods with the same kinetic as the two parents (Supplementary Table S6). The results obtained confirmed that manual crossings can be efficiently performed in A. evenia.

\section{DISCUSSION}

In this article, we determined that A. evenia is an appropriate species to constitute a new model legume for studying the Nod-independent symbiotic process. Indeed, in addition to its diploid character, this species gathers several advantageous features suitable for the development of functional genetic approaches. A. evenia has a short generation time-flowering can be triggered by short days - and a seed production both profuse and long lasting, making biological material rapidly and abundantly available. The germination level is close to $100 \%$, the in vitro culture can be done without difficulty, and the plantlets are small; these are additional advantageous characteristics, making its use easy in the laboratory conditions, too. With the Agrobacterium rhizogenes-mediated root transformation procedure established for A. indica (Bonaldi et al. 2010a), transgenic A. evenia roots can be readily generated on chimerical plants. The transformed roots are efficiently nodulated and the nodules are functional, indicating that the integration of the Ti plasmid does not perturb the Nod-independent symbiotic process as previously reported (Bonaldi et al. 2010a). The hairy root system is a common transformation procedure used to study the nitrogen-fixing symbiosis in the other model legumes, given the fact that the symbiotic genes are mainly expressed in roots and nodules (Boisson-Dernier et al. 2001; Kumagai and Kouchi 2003). This indicates that the hairy-root system is a valuable and appropriate tool for functional and molecular analysis of the Nod-independent process in A. evenia.

Importantly, A. evenia is efficiently nodulated by the nodgene-lacking ORS278 strain. This strain has been extensively analyzed, with its genome being completely sequenced and a collection of 25,000 Tn5 mutants developed (Bonaldi et al. 2010b; Giraud et al. 2007). Derived strains with reporter genes

Table 2. Agrobacterium rhizogenes-mediated transformation of Aeschynomene evenia with the binary vector pCAMBIA2301(35S-green fluorescent protein $[\mathrm{GFP}])^{\mathrm{Z}}$

\begin{tabular}{|c|c|c|c|c|c|c|}
\hline $\begin{array}{l}\text { Agrobacterium } \\
\text { rhizogenes strain }\end{array}$ & $\begin{array}{l}\text { Plants } \\
\text { tested }\end{array}$ & $\begin{array}{c}\text { Composite plants } \\
(\%)\end{array}$ & $\begin{array}{c}\text { Plants } \\
\text { inoculated }\end{array}$ & $\begin{array}{l}\text { Nodulated plants } \\
\text { with ORS278 }(\%)\end{array}$ & $\begin{array}{l}\text { Nodules/plant } \\
\text { (14 dpi) }\end{array}$ & $\begin{array}{l}\text { Nitrogenase } \\
\text { activity (\%) }\end{array}$ \\
\hline ARqua1 & 90 & 57 & 30 & 87 & $8.3 \pm 6.1$ & 85 \\
\hline NT & 90 & $\ldots$ & 30 & 100 & $8.2 \pm 3.2$ & 100 \\
\hline
\end{tabular}

${ }_{\mathrm{z}}$ Nodulation data given for the ARqua1 line are calculated for the transformed (GFP positive) roots; dpi = days post inoculation and NT $=$ not transformed. 
are also available and can be conveniently used for microscopic observations (Bonaldi et al. 2011). Therefore, we propose the use of the couple A. evenia-Bradyrhizobium sp. ORS278 as symbiotic model to study the Nod-independent process.

The small genome size for A. evenia, approximately 460 $\mathrm{Mb}$, is also a very positive property. This size is similar to those of the two model legumes $M$. truncatula and L. japonicus. Small genome sizes are not widespread in legumes (Zhu et al. 2005). This fact is well illustrated with Arachis hypogaea and Stylosanthes seabrana, two species closely related to $A$. evenia, which display genome sizes of 5,080 and 2,650 Mb, respectively (Fig. 1). To date, the genome of four legumes has been sequenced: the two model plants $M$. truncatula and $L$. japonicus and the agriculturally important soybean (Glycine max), and pigeonpea (Cajanus cajan), these two latter displaying genomes of 1,140 and $833 \mathrm{Mb}$, respectively (Sato et al. 2008; Schmutz et al. 2010; Varshney et al. 2012; Young et al. 2011). With the recent advances in DNA sequencing techniques and the possibility of comparative genomics between legumes (Bertioli et al. 2009; Cannon et al. 2009), we can anticipate that the A. evenia genome sequence will be accessible in a few years. In this respect, we are currently engaged in a 454 analysis of $A$. evenia transcriptome in order to establish first genomic resources. A small genome size also constitutes an advantage for the development of a forward genetic approach, such as mutagenesis, because the localization of the mutated gene leading to a symbiotic deficiency will be facilitated (Tadege et al. 2009). With this perspective, we have identified various polymorphic accessions with similar nodulation characteristics and developed a crossing technique between them in order to make possible the development of a genetic map. Taking advantage of the self-fertilizing and genetically homozygous character of this plant, we are currently breeding different pure lines that should be available within one year for use. They will then be tested for their suitability as mapping parents to generate vigorous F2 plants displaying a normal segregation of the molecular markers. The high level of polymorphism observed between the accessions, even within each variety, the results obtained in this study with the manual hybridizations, and the evidence of crossings occurring naturally (J.-F. Arrighi, personal observation) support the possibility of developing an effective mapping F2 population for A. evenia.

The development of new high-throughput technologies, the current knowledge of the rhizobium-legume symbiosis, and our background with the Aeschynomene-photosynthetic Bradyrhizobium interaction will accelerate the establishment of $A$. evenia as a bona fide model legume. Therefore, it is expected to be far less time consuming than it was two decades ago for Medicago and Lotus spp. (Barker et al. 1990; Handberg and Stougaard 1992). But this will also require financial support and involvement of the legume research community. Therefore, the questions that should be addressed are: is there a necessity for a new model legume and which real benefits can we expect from it?

The fundamental differences observed in the symbiotic process between Aeschynomene-photosynthetic Bradyrhizobium and the "conventional" rhizobium-legume symbiosis, at the level of the infection process, nodule ontogenesis, and nodulation signaling pathways, ensure that the model $A$. evenia will not be redundant. It should shed new light on the endosymbiotic mechanisms between plant and bacteria. Although the absence of a requirement of NF to trigger symbiosis has been identified to date in only some species belonging to the Aeschynomene genus, the mode of bacterial invasion and nodule organogenesis described in Aeschynomene spp. is largely shared in tropical and Mediterranean legumes, including species of prime agronomic importance such as Arachis and Lupi-
A

(a)

(b)
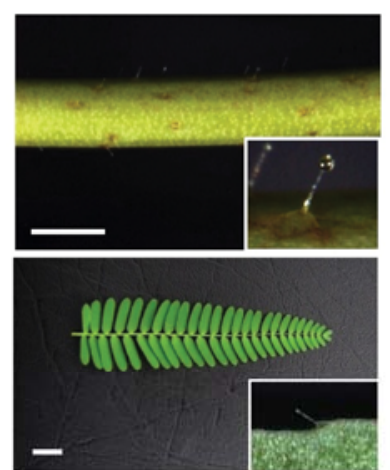

(c)

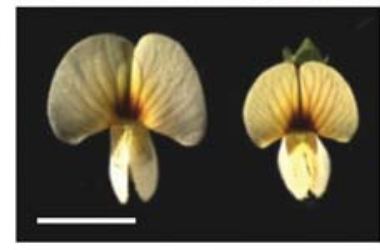

(d)

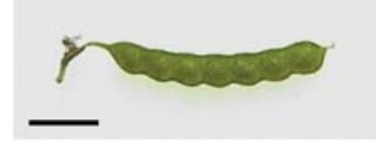

var. evenia
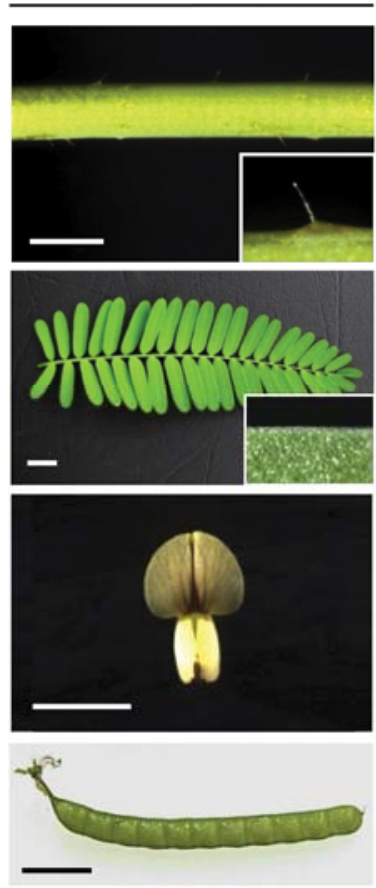

B

(a)

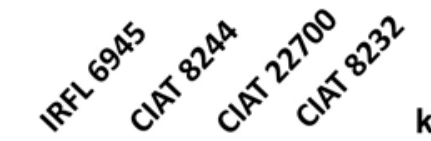

(a)

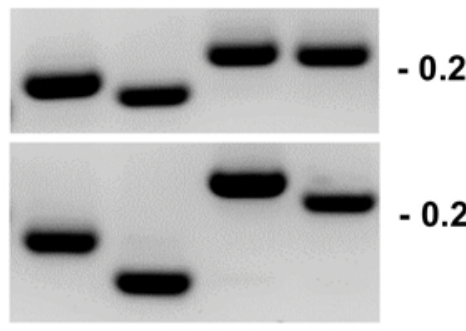

(c)

\section{(b)}

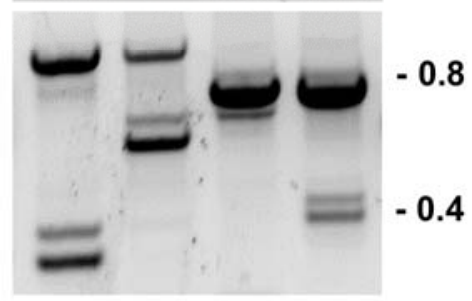

(d)

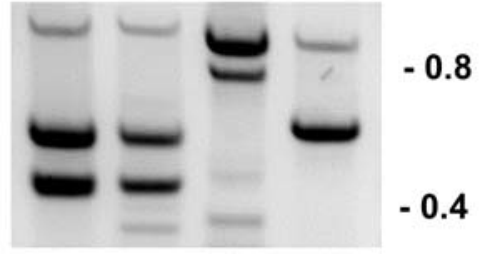

Fig. 5. Phenotypic and genetic polymorphism. A, Phenotypic variations in Aeschynomene evenia which distinguish the varieties evenia and serrulata on stems with a zoom on trichomes (a), leaves with a zoom on folioles (b), flowers (c), and pods (d). Scale bars $=6 \mathrm{~mm}$. B, Genetic diversity among selected $A$. evenia accessions revealed with the markers AiSSR4 and 6 (a and b) and RAPD OPAB11 and L07 (c and d). Accessions IRFL6945 and CIAT 8244 belong to the variety serrulata and accessions CIAT 22700 and CIAT 8232 to the variety evenia. 
nus species, as well as many forage legumes found in the Stylosanthes and Aeschynomene genera (Bishop et al. 1997; Sprent 2009). Therefore, A. evenia appears to be a good model to better understand the molecular basis of this invasion pathway in tropical legumes, for which our knowledge remains extremely limited due to the absence of appropriate genetic tools.

Interestingly, genetic analysis in L. japonicus using double mutants has shown that single-cell infection could also occur in this species, without the formation of infection threads, independently of plant NF receptors and bacterial NF (Madsen et al. 2010). This infection process was suggested to correspond to the ground state of the rhizobial infection, which must have been maintained during evolution in some legumes such as Aeschynomene spp. (Bonaldi et al. 2011; Madsen et al. 2010). However, in the artificial system developed in L. japonicus, infection events happened with an extremely low frequency. Therefore, using A. evenia to decipher the Nod-independent molecular mechanisms would be relevant to uncover the basic underlying processes of nodulation. This knowledge could be of prime importance to identify new strategies to engineer nitrogen-fixing nodules in cereals, which remains one of the major challenges for the 21st century (Beatty and Good 2011; Charpentier and Oldroyd 2010). Therefore, yes, there is definitively a great interest in the emerging of A. evenia as a new model legume.

\section{MATERIALS AND METHODS}

Plant material and culture conditions.

All the accessions of Aeschynomene used in this study, their geographic origin, and their sources are listed in Supplementary Tables S2 and S3. IRFL6945 was initially selected by the Indian River Research and Education Center (Florida, U.S.A.) and was used in this study for all the experiments unless indicated otherwise.

A. evenia seeds were scarified with concentrated (95\%) sulfuric acid for $40 \mathrm{~min}$. Subsequently, the seeds were abundantly rinsed with sterile water, surface sterilized with sodium hypochlorite $(3 \%)$ for $5 \mathrm{~min}$, and rinsed abundantly again. They were then incubated overnight in sterile water at room temperature, transferred onto $0.8 \%$ water agar plates, and put upside-down for another night at $34^{\circ} \mathrm{C}$ to induce germination.

For in vitro culture, 1-day-old seedlings were asceptically transferred to test tubes filled with $55 \mathrm{ml}$ of buffered nodulation medium (BNM) medium (Ehrhardt et al. 1992). To allow passage of the radical, a small hole in the aluminum foil cap was made using a sterile toothpick. Seedlings were grown in a small greenhouse containing 1 liter of sterile water and placed in a $28^{\circ} \mathrm{C}$ growth chamber with a 16 -h light regime (light intensity $=130 \mu \mathrm{E}$ ) and $70 \%$ humidity.

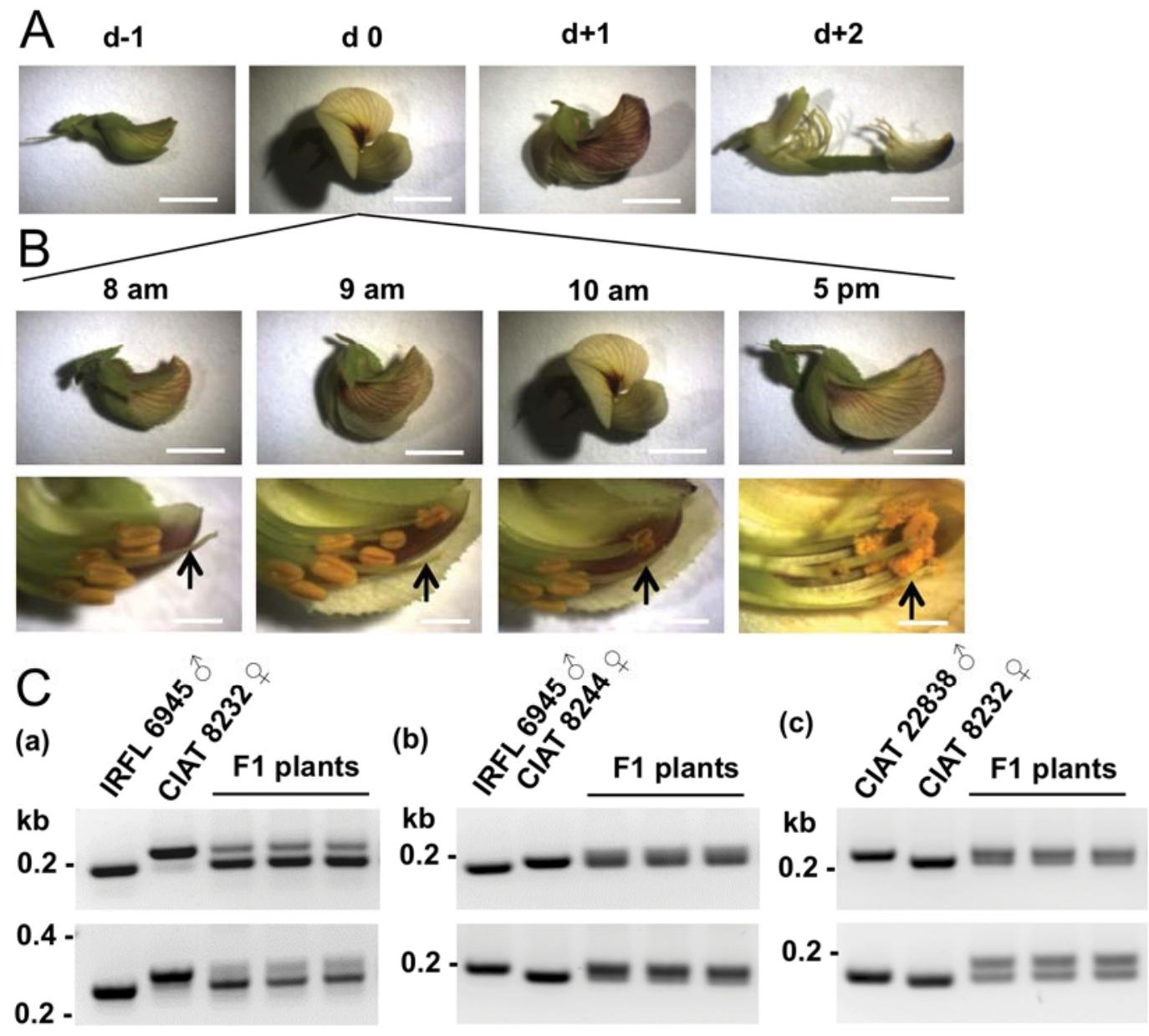

Fig. 6. Flower development and cross-pollination. A, Series of developmental stages covering the flower bud (d-1), flower opening (d 0), flower senescing $(\mathrm{d}+1)$, and emergence of an young pod $(\mathrm{d}+2)$. B, Analysis on d 0 at different time-points (8:00, 9:00, and 10:00 a.m. and 5:00 p.m.) with a detailed view of stamens and pistil (arrow) in dissected flowers. Note that sexual pieces are always kept enclosed within petals, and that anthesis precedes flower opening and is directed toward the stigma. Scale bars $=5 \mathrm{~mm}$ for entire flowers and $1 \mathrm{~mm}$ for dissected flowers. C, Genotyping of F1 seedlings obtained by crossing polymorphic accessions: (a) intervarietal crossing between IRFL6945 (var. serrulata) and CIAT 8232 (var. evenia) verified using AiSSR4 (upper) and AiSSR43 (down); (b) crossing within the variety serrulata between IRFL6945 and CIAT 8244 verified with AiSSR23 (upper) and AiSSR6 (down); (c) crossing within the variety evenia between CIAT 22838 and CIAT 8232 verified with AiSSR4 (upper) and AiSSR23 (down). 
For plant culture in the greenhouse, 1-day-old seedlings were transferred to plastic pots $(8 \mathrm{~cm}$ in diameter) filled with atapulgite. The plants were grown at 26 to $36^{\circ} \mathrm{C}$ with a relative humidity of 70 to $80 \%$. Plants were watered regularly and supplied once a week with a plant nutrition solution (Bertrand et al. 2000) supplemented with $1 \mathrm{mM} \mathrm{KNO}_{3}$ until inoculation.

Rooting was performed in the greenhouse using 30- to 40$\mathrm{cm}$ cuttings that were placed in water or directly in plastic pots filled with atapulgite. Both methods efficiently led to adventives root development.

\section{Plant nodulation and ARA.}

Nodulation tests were done using Bradyrhizobium sp. strains ORS278, ORS285, and BTAi1 (Bonaldi et al. 2011; Giraud et al. 2007) and analysis of the infection process using strain ORS285 $\Delta$ nodB carrying the pMG103-nptII-GFP plasmid (Bonaldi et al. 2011).

Bradyrhizobium sp. strains were cultivated for 7 days in yeast-manitol liquid medium at $34^{\circ} \mathrm{C}$. Ten-day-old plants were inoculated with $1 \mathrm{ml}$ of bacterial culture with an optical density at $600 \mathrm{~nm}$ adjusted to 1 .

Nitrogen-fixing activity was estimated on the entire plant, $14 \mathrm{dpi}$, by measurement of ARA and the dry mass was measured as published by Bonaldi and associates (2010a and b).

\section{Agrobacterium rhizogenes-mediated root transformation.}

The procedure was mostly similar to the one set up for $A$. indica (Bonaldi et al. 2010a) using direct application of Agrobacterium rhizogenes on freshly sectioned radicles of 4-dayold seedlings. It was adapted to A. evenia for the following points. After hairy root emergence, the plantlets were subcultured twice at 7-day intervals on solid half-strength Murashige Skoog medium containing cefotaxim (300 mg/liter). Then, the co-transformed plantlets were transferred to Falcon tubes, containing liquid $\mathrm{BNM}$ supplemented with $1 \mathrm{mM} \mathrm{KNO}_{3}$, which were covered with aluminum to protect the root system from light.

ARqua1 strains carrying the pCaMV35S::GFP and pCaMV35S::gusA-int constructs were described by Bonaldi and associates (2010a).

\section{Light and confocal microscopy.}

Microscopic observations were performed using either an optical macroscope (Nikon AZ100; Champigny-sur-Marne, France) or a microscope (Olympus, Rungis, France). For confocal microscopy, fresh roots and nodules were sectioned, stained and observed as indicated by Bonaldi and associates (2011).

\section{Crossing procedure.}

Emasculation of the pollen-recipient flower was performed early in the morning at a stage when the pistil had already elongated but the anthers had not. For this, with extra-fine forceps, the joint keel petals of the recipient flower were put aside and the 10 non-open stamens were carefully removed. Approximately $2 \mathrm{~h}$ later, pollen-donor flowers were collected and their petals removed. Then, the stamens covered with freshly released pollen were applied to the stigma of the recipient flower in order to saturate its surface with exogenous pollen. The pollinated pistil was then gently placed back under the petals. The success of crosses was indicated by the development of small, straight pods that became visible 2 days after pollination.

\section{DNA content measurements.}

DNA content was determined using a CyFlow SL3 cytometer with 532 nm laser (Partec, Sainte Geneviève des Bois, France). Measurements were as described by Blondon and associates
(1994) using propidium iodide at $50 \mu \mathrm{g} / \mathrm{ml}$, Galbraith's nuclear isolation buffer supplemented with $1 \%$ polyvinylpyrrolidine and $5 \mathrm{mM}$ sodium metabisulfite, and Lycopersicum esculentum 'Roma' $(2 \mathrm{C}=1.99 \mathrm{pg})$ as the routine internal standard. Each genome size estimation resulted from measurements for three plants per accession. The $1 \mathrm{C}$ value was calculated and expressed as $\mathrm{Mb} / 1 \mathrm{C}$ using the conversion factor $1 \mathrm{pg}$ DNA = $978 \mathrm{Mb}$.

\section{DNA isolation and marker typing.}

Total genomic DNA was isolated from new leaves of plants using the cetyltrimethylammonium bromide extraction method. SSR motifs present in A. indica EST (F. Cartieaux, unpublished data) were identified using the ESTtik pipeline developed by CIRAD (Centre de Coopération Internationale en Recherche Agronomique pour le Dévelppement, Montpellier, France). Primers flanking the SSR motifs were designed using the Primer3 program and then tested for PCR amplification and length polymorphism in A. evenia (Supplementary Table S5). For RAPD markers, primers were designed by Operon Technologies (Alameda, CA, U.S.A.) (Supplementary Table S7). Genomic DNA from A. evenia accessions were used as templates for PCR marker amplification as described by Thoquet and associates (2002).

\section{Chromosome preparation.}

Chromosome preparation was adapted from d'Hont and associates (1996). Healthy root tips (5 mm long) of freshly germinated seedlings were placed into a solution of 8-hydroxyquinoline $(0.04 \%)$ for $4 \mathrm{~h}$ at room temperature. They were then fixed in 3:1 ethanol/glacial acetic acid for at least $24 \mathrm{~h}$ and stored in $70 \%$ ethanol at $4^{\circ} \mathrm{C}$. Fixed root apices were hydrolyzed in $\mathrm{HCl}(0.25 \mathrm{~N})$ for $10 \mathrm{~min}$; then digested for $30 \mathrm{~min}$ at $37^{\circ} \mathrm{C}$ with a mixture of pectolytic enzymes containing $1 \%$ cytohelicase, $1 \%$ cellulase 'Onozuka' R10, and $1 \%$ pectolyase Y-23 (Duchefa, Haarlem, The Netherlands) in $10 \mathrm{mM}$ citrate buffer, pH 4.5; and, finally, incubated in deionized water. Subsequently, the meristematic cells were transferred to an acidprecleaned slide and spread in one drop of 3:1 ethanol/glacial acetic acid, and the slides were air dried. The quality of the slides was controlled by microscopic observation under phase contrast optics. Slides were stored at room temperature until needed.

\section{Fluorescent in situ hybridization.}

Slides were treated with RNase (Sigma-Aldrich, St. Louis) $(1 \mu \mathrm{g} / \mathrm{ml})$ in a moist chamber at $37^{\circ} \mathrm{C}$ for $45 \mathrm{~min}$, denatured in a solution of $70 \%$ formamide in $2 \times \mathrm{SSC}(1 \times \mathrm{SSC}$ is $0.15 \mathrm{M}$ $\mathrm{NaCl}$ plus $0.015 \mathrm{M}$ sodium citrate) at $80^{\circ} \mathrm{C}$ for $3 \mathrm{~min}$, then dehydrated through an ethanol series $(70,90$, and $100 \%)$ at $-20^{\circ} \mathrm{C}$. Probes consisted of pTA 71 (rDNA genes 18S-5.8S-25S) (Gerlach and Bedbrook 1979; Salvo-Garrido et al. 2001) and 5S rRNA (Gerlach and Dyer 1980), labeled by random priming with digoxigenin-11-dTTP (High Prime DNA Labeling Kit, Roche, Mannheim, Germany) and biotine-14-dUP (Invitrogen Life Technology, San Diego, CA, U.S.A.), respectively. The hybridization mixture $(50 \mu \mathrm{l}$ per slide) consisted of $50 \%$ formamide, $10 \%$ dextran sulfate, $2 \times \mathrm{SSC}, 1 \%$ sodium dodecyl

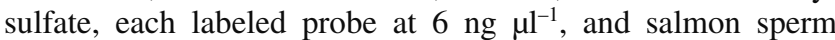
DNA at $0.5 \mu \mathrm{g} \mu \mathrm{l}^{-1}$ as a distant competitor. The hybridization mixture was denatured for $10 \mathrm{~min}$ in boiling water and dispensed on the slides. Hybridization was performed overnight in a moist chamber at $37^{\circ} \mathrm{C}$. After hybridization, slides were washed for $10 \mathrm{~min}$ in $2 \times \mathrm{SSC}, 0.5 \times \mathrm{SSC}$, and $0.1 \times \mathrm{SSC}$ at $42^{\circ} \mathrm{C}$. Biotinylated probes were immunodetected with TexasRed conjugated avidin antibodies (ABCYC). Digoxigeninlabeled probes were detected with digoxigenin antibody conju- 
gated with fluoresceine isothiocyanate (ABCYS). The chromosomes were mounted in Vectashield antifade solution (Vector Laboratories) containing 4',6-diamidino-2-phenylindole at 2.5 $\mu \mathrm{g} \mathrm{ml} \mathrm{m}^{-1}$ as counterstaining. Fluorescence images were captured separately using a cooled high-resolution black and white CCD camera (Orca, Hamamatsu, Tokyo) and a Leica DMRAX2 fluorescence microscope. The camera was interfaced to a PC running the Volocity software (Perkin-Elmer, Tokyo).

\section{ACKNOWLEDGMENTS}

We thank L. G. Santos Meléndes (CIAT, Columbia) for provision of the Aeschynomene evenia accessions used in this study; N. Rezkallah (LSTM, IRD) for technical assistance; D. Foncéka (CIRAD, France) for advice in the set up of the manual crossing method; M. Bourge (Imagif Platform, CNRS, Gif-sur-Yvette) for help in cytometry; and P. Czernic, M. Lepetit, and M. Lebrun (LSTM, IRD) for their critical reading of the manuscript. J.-F. Arrighi and E. Giraud supervised the project and wrote the article. J.-F. Arrighi analyzed the phenotypic and genetic polymorphism and developed the manual crossing procedure. The Agrobacterium rhizogenesmediated root transformation was set up by F. Cartieaux, D. Patrel, and S. Fabre. The infection and nodulation process was studied by E. Giraud and D. Gully. DNA measurements by cytophotometry flux were performed by S. Brown and cytogenetic analysis conjointly by M. Rodier-Goud and J.-F. Arrighi. J. Fardoux, M. Boursot, and C. Chaintreuil contributed to plant culture and characterization. This work was supported by a grant from the French National Research Agency (ANR-SESAM-2010-BLAN-170801).

\section{LITERATURE CITED}

Arumuganathan, K. E., and Earle, E. D. 1991. Nuclear DNA content of some important plant species. Plant Mol. Biol. Rep. 9:208-218.

Bairiganjan, G. C., and Patnaik, S. N. 1989. Chromosomal evolution in Fabaceae. Cytologia 54:51-64.

Barker, D. G., Bianchi, S., Blondon, F., Dattée, Y., Duc, G., Essad, S., Flament, P., Gallusci, P., Génier, G., Guy, P., Muel, X., Tourneur, J., Dénarié, J., and Huguet, T. 1990. Medicago truncatula, a model plant for studying the molecular genetics of the rhizobium-legume symbiosis. Plant Mol. Biol. Rep. 8:40-49.

Beatty, P. H., and Good, A. G. 2011. Plant science. Future prospects for cereals that fix nitrogen. Science 333:416-417.

Bertioli, D. J., Moretzsohn, M. C., Madsen, L. H., Sandal, N., Leal-Bertioli, S. C., Guimaraes, P. M., Hougaard, B. K., Fredslund, J., Schauser, L., Nielsen, A. M., Sato, S., Tabata, S., Cannon, S. B., and Stougaard, J. 2009. An analysis of synteny of Arachis with Lotus and Medicago sheds new light on the structure, stability and evolution of legume genomes. BMC Genomics 10:45-55.

Bertrand, H., Plassard, C., Pinochet, X., Touraine, B., Normand, P., and Cleyet-Marel, J. C. 2000. Stimulation of the ionic transport system in Brassica napus by a plant growth-promoting rhizobacterium (Achromobacter sp.). Can. J. Microbiol. 46:229-236.

Bielig, L. M. 1997. Chromosome numbers in the forage legume genus, Aeschynomene L. SABRAO J. 29:33-39.

Bishop, H. G., Cook, B. G., English, B. H., Bushell, J. J., and Hilder, T. B. 1997. More Aeschynomene pasture legumes for the tropics and subtropics. In: Proc. XVIII Int. Grassland Congress.

Blondon, F., Marie, D., Brown, S. C., and Kondorosi, A. 1994. Genome size and base composition in Medicago sativa and M. truncatula species. Genome 37:264-270.

Boisson-Dernier, A., Chabaud, M., Garcia, F., Becard, G., Rosenberg, C., and Barker, D. G. 2001. Agrobacterium rhizogenes-transformed roots of Medicago truncatula for the study of nitrogen-fixing and endomycorrhizal symbiotic associations. Mol. Plant-Microbe Interact. 14:695700

Bonaldi, K., Gherbi, H., Franche, C., Bastien, G., Fardoux, J., Barker, D., Giraud, E., and Cartieaux, F. 2010a. The Nod factor-independent symbiotic signaling pathway: Development of Agrobacterium rhizogenesmediated transformation for the legume Aeschynomene indica. Mol. Plant-Microbe Interact. 23:1537-1544.

Bonaldi, K., Gourion, B., Fardoux, J., Hannibal, L., Cartieaux, F., Boursot, M., Vallenet, D., Chaintreuil, C., Prin, Y., Nouwen, N., and Giraud, E. 2010b. Large-scale transposon mutagenesis of photosynthetic Bradyrhizobium sp. strain ORS278 reveals new genetic loci putatively important for nod-independent symbiosis with Aeschynomene indica. Mol. PlantMicrobe Interact. 23:760-770.

Bonaldi, K., Gargani, D., Prin, Y., Fardoux, J., Gully, D., Nouwen, N., Goormachtig, S., and Giraud, E. 2011. Nodulation of Aeschynomene afraspera and A. indica by photosynthetic Bradyrhizobium sp. strain ORS285: The nod-dependent versus the nod-independent symbiotic interaction. Mol. Plant-Microbe Interact. 24:1359-1371.

Cannon, S. B., May, G. D., and Jackson, S. A. 2009. Three sequenced legume genomes and many crop species: Rich opportunities for translational genomics. Plant Physiol. 151:970-977.

Chaintreuil, C., Boivin, C., Dreyfus, B., Giraud, E. 2001. Characterization of the common nodulation genes of the photosynthetic Bradyrhizobium sp. ORS285 reveals the presence of a new insertion sequence upstream of nodA. FEMS (Fed. Eur. Microbiol. Soc.) Microbiol. Lett. 194:83-86.

Chandler, M. R. 1978. Some observations on infection of Arachis hypogaea L. by Rhizobium. J. Exp. Bot. 29:749-755.

Chandler, M. R., Date, R. A., and Roughley, R. J. 1982. Infection and root nodule development in Stylosanthes species by Rhizobium. J. Exp. Bot. 33:47-57.

Chandra, A., and Kaushal, P. 2009. Identification of diploid Stylosanthes seabrana accessions from existing germplasm of $S$. scabra utilizing genome-specific STS markers and flow cytometry, and their molecular characterization. Mol. Biotechnol. 42:282-291.

Charpentier, M., and Oldroyd, G. 2010. How close are we to nitrogen-fixing cereals? Curr. Opin. Plant Biol. 13:556-564.

D'Hont, A., Grivet, L., Feldmann, P., Rao, S., Berding, N., and Glaszmann, J. C. 1996. Characterisation of the double genome structure of modern sugarcane cultivars (Saccharum spp.) by molecular cytogenetics. Mol. Gen. Genet. 250:405-413.

Ehrhardt, D. W., Atkinson, E. M., and Long, S. R. 1992. Depolarization of alfalfa root hair membrane potential by Rhizobium meliloti factors. Science 256:998-1000.

Gerlach, W. L., and Bedbrook, J. R. 1979. Cloning and characterization of ribosomal RNA genes from wheat and barley. Nucleic Acid Res. 7:1869-1885

Gerlach, W. L., and Dyer, T. A. 1980. Sequence organization of the repeating units in the nucleus of wheat which contain $5 \mathrm{~S}$ rRNA genes. Nucleic Acids Res. 8:4851-4865.

Gherbi, H., Markmann, K., Svistoonoff, S., Estevan, J., Autran, D. Giczey, G., Auguy, F., Péret, B., Laplaze, L., Franche, C., Parniske, M., and Bogusz, D. 2008. SymRK defines a common genetic basis for plant root endosymbioses with arbuscular mycorrhiza fungi, rhizobia, and Frankiabacteria. Proc. Natl. Acad. Sci. U.S.A. 105:4928-4932.

Giraud, E., Hannibal, L., Fardoux, J., Vermeglio, A., and Dreyfus, B. 2000. Effect of Bradyrhizobium photosynthesis on stem nodulation of Aeschynomene sensitiva. Proc. Natl. Acad. Sci. U.S.A. 97:14795-14800.

Giraud, E., Moulin, L., Vallenet, D., Barbe, V., Cytryn, E., Avarre, J.C., Jaubert, M., Simon, D., Cartieaux, F., Prin, Y., Bena, G., Hannibal, L., Fardoux, J., Kojadinovic, M., Vuillet, L., Lajus, A., Cruveiller, S., Rouy, Z., Mangenot, S., Segurens, B., Dossat, C., Franck, W.L., Chang, W.S., Saunders, E., Bruce, D., Richardson, P., Normand, P., Dreyfus, B., Pignol, D., Stacey, G., Emerich, D., Vermeglio, A., Medigue, C., and Sadowsky, M. 2007. Legumes symbioses: Absence of Nod genes in photosynthetic Bradyrhizobia. Science 316:1307-1312.

Gonzales-Sama, A., Lucas, M. M., de Felipe, M. R., and Pueyo, J. J. 2004. An unusual infection mechanism and nodule morphogenesis in white lupin (Lupinus albus). New Phytol. 163:371-380.

Handberg, K., and Stougaard, J. 1992. Lotus japonicus, an autogamous, diploid legume species for classical and molecular genetics. Plant J. 2:487-496.

Jones, K. M., Kobayashi, H., Davies, B. W., Taga, M. E., and Walker, G. C. 2007. How rhizobial symbionts invade plants: The Sinorhizobium medicago model. Nat. Rev. Microbiol. 5:619-633.

Kretschmer, A. E., Pitman, W. D., Bullock, R. C., and Wilson, T. C. 1994 Aeschynomene evenia $\mathrm{C}$-Wright (Evenia aeschynomene), a perennial legume for grazing in south Florida. Soil Crop Sci. Soc. Fla. Proc. 53:59.

Kretschmer, A. E., Pitman, W. D., Wilson, T. C., and Bullock, R. C. 1997. Registration of Evenia aeschynomene IRFL 6945 germplasm. Crop Sci 37.

Kumagai, H., and Kouchi, H. 2003. Gene silencing by expression of hairpin RNA in Lotus japonicus roots and root nodules. Mol. Plant-Microbe Interact. 16:663-668.

Madsen, L. H., Tirichine, L., Jurkiewicz, A., Sullivan, J. T., Heckmann, A B., Bek, A. S., Ronson, C. W., James, E. K., and Stougaard, J. 2010 The molecular network governing nodule organogenesis and infection in the model legume Lotus japonicus. Nat. Commun. 1:10.

Marie, D., and Brown, S. C. 1993. A cytometric exercise in plant DNA histograms, with $2 \mathrm{C}$ values for seventy species. Biol. Cell 78:41-51.

Markmann, K., and Parniske, M. 2009. Evolution of root endosymbiosis with bacteria: How novel are nodules? Trends Plant Sci. 14:77-86.

Masson-Boivin, C., Giraud, E., Perret, X., and Batut, J. 2009. Establishing nitrogen-fixing symbiosis with legumes: How many rhizobium recipes? Trends Microbiol. 17:458-466. 
Naganowska, B., Wolko, B., Sliwinska, E., and Kaczmarek, Z. 2003. Nuclear DNA content variation and species relationships in the genus $\mathrm{Lu}$ pinus (Fabaceae). Ann. Bot. 92:349-355.

Oldroyd, G. E., Murray, J. D., Poole, P. S., and Downie, J. A. 2011. The rules of engagement in the legume-rhizobial symbiosis. Annu. Rev. Genet. 45:119-144.

Parniske, M. 2008. Arbuscular mycorrhiza: The mother of plant root endosymbioses. Nat. Rev. Microbiol. 6:763-775.

Quandt, H. J., Puhler, A., and Broer, I. 1993. Transgenic root-nodules of Vicia hirsute - a fast and efficient system for the study of gene-expression in indeterminate-type nodules. Mol. Plant-Microbe Interact. 6:699-706.

Rudd, V. E. 1955. The American species of Aeschynomene. Contrib. U. S. Natl. Herb. 32:1-172.

Salvo-Garrido, H., Travella, S., Schwarzacher, T., Harwood, W. A., and Snape, J. W. 2001 An efficient method for the physical mapping of transgenes in barley using in situ hybridization. Genome 44:104-110.

Sato, S., Nakamura, Y., Kaneko, T., Asamizu, E., Kato, T., Nakao, M., Sasamoto, S., Watanabe, A., Ono, A., Kawashima, K., Fujishiro, T., Katoh, M., Kohara, M., Kishida, Y., Minami, C., Nakayama, S., Nakazaki, N., Shimizu, Y., Shinpo, S., Takahashi, C., Wada, T., Yamada, M., Ohmido, N., Hayashi, M., Fukui, K., Baba, T., Nakamichi, T., Mori, H. and Tabata, S. 2008. Genome structure of the legume, Lotus japonicus. DNA Res. 15:227-239.

Schmutz, J., Cannon, S. B., Schlueter, J., Ma, J., Mitros, T., Nelson, W. Hyten, D. L., Song, Q., Thelen, J. J., Cheng, J., Xu, D., Hellsten, U., May, G. D., Yu, Y., Sakurai, T., Umezawa, T., Bhattacharyya, M. K., Sandhu, D., Valliyodan, B., Lindquist, E., Peto, M., Grant, D., Shu, S., Goodstein, D., Barry, K., Futrell-Griggs, M., Abernathy, B., Du, J., Tian, Z., Zhu, L., Gill, N., Joshi, T., Libault, M., Sethuraman, A., Zhang, X. C., Shinozaki, K., Nguyen, H.T ., Wing, R. A., Cregan, P., Specht, J., Grimwood. J., Rokhsar, D., Stacey, G., Shoemaker, R. C., and Jackson, S. A. 2010. Genome sequence of the palaeopolyploid soybean. Nature 463:178-183.

Sprent, J. I. 2007. Evolving ideas of legume evolution and diversity: A taxonomic perspective on the occurrence of nodulation. New Phytol. 174:11-25.

Sprent, J. I. 2008. 60Ma of legume nodulation. What's new? What's changing? J. Exp. Bot. 59:1081-1084.

Sprent, J. I. 2009. Legume Nodulation, A Global Perspective, 1st ed. Wiley-Blackwell.

Sprent, J. I., and James, E. K. 2008. Legume-rhizobial symbiosis: An anorexic model? New Phytol. 179:3-5.

Tadege, M., Wang, T. L., Wen, J., Ratet, P., and Mysore, K. S. 2009. Mutagenesis and beyond! Tools for understanding legume biology. Plant Physiol. 151:978-984.

Temsch, E. M., and Greilhuber, J. 2000. Genome size variation in Arachis hypogaea and A. monticola re-evaluated. Genome 43:449-451.

Thoquet, P., Ghérardi, M., Journet, E. P., Kereszt, A., Ane, J. M., Prospéri, J. M., and Huguet, T. 2002. The molecular genetic linkage map of the model legume Medicago truncatula: An essential tool for comparative legume genomics and the isolation of agronomically important genes. BMC Plant Biol. 2:1.

Varshney, R. K., Chen, W., Li, Y., Bharti, A. K., Saxena, R. K., Schlueter, J. A., Donoghue, M. T. A., Azam, S. Fan G., Whaley A. M., Farmer, A. D., Sheridan, J., Iwata, A., Tuteja, R. Penmetsa, R. V., Wu, W.,
Upadhyaya, H. D., Yand S. P., Shah, T., Saxena, K. B., Michael, T., McCombie, W. R., Yang, B., Zhang, G., Yang, H., Wang, J., Spillane, C., Cook, D. R., May, G. D., Xu, X., and Jackson, S. A. 2012. Draft genome sequence of pigeon pea (Cajanus cajan), an orphan legume crop of resource-poor farmer. Nature 30:83-89.

Vendramini, J., Newman, Y. C., Silveira, M. L. A., Chambliss, R. S., Kalmbacher, R. S., and Adjei, M. B. 2010. Aeschynomene. Florida Forage Handbook. Agronomy Department, IFAS, University of Florida SSAGR-61.

Young, N. D., Debellé, F., Oldroyd, G. E., Geurts, R., Cannon, S. B., Udvardi, M. K., Benedito, V. A., Mayer, K. F., Gouzy, J., Schoof, H., Van de Peer, Y., Proost, S., Cook, D. R., Meyers, B. C., Spannagl, M., Cheung, F., De Mita, S., Krishnakumar, V., Gundlach, H., Zhou, S., Mudge, J., Bharti, A. K., Murray, J. D., Naoumkina, M. A., Rosen, B., Silverstein, K. A., Tang, H., Rombauts, S., Zhao, P. X., Zhou, P., Barbe, V., Bardou, P., Bechner, M., Bellec, A., Berger, A., Berges, H., Bidwell, S., Bisseling, T., Choisne, N., Couloux, A., Denny, R., Deshpande, S., Dai, X., Doyle, J. J., Dudez, A. M., Farmer, A. D., Fouteau, S., Franken, C., Gibelin, C., Gish, J., Goldstein, S., Gonzalez, A. J., Green, P. J., Hallab, A., Hartog, M., Hua, A., Humphray, S. J., Jeong, D. H., Jing, Y., Jocker, A., Kenton, S. M., Kim, D. J., Klee, K., Lai, H., Lang, C., Lin, S., Macmil, S. L., Magdelenat, G., Matthews, L., McCorrison, J., Monaghan, E. L., Mun, J. H., Najar, F. Z., Nicholson, C., Noirot, C., O’Bleness, M., Paule, C. R., Poulain, J., Prion, F., Qin, B., Qu, C., Retzel, E. F., Riddle, C., Sallet, E., Samain, S., Samson, N., Sanders, I., Saurat, O., Scarpelli, C., Schiex, T., Segurens, B., Severin, A. J., Sherrier, D. J., Shi, R., Sims, S., Singer, S. R., Sinharoy, S., Sterck, L., Viollet, A., Wang, B. B., Wang, K., Wang, M., Wang, X., Warfsmann, J., Weissenbach, J., White, D. D., White, J. D., Wiley, G. B., Wincker, P., Xing, Y., Yang, L., Yao, Z., Ying, F., Zhai, J., Zhou, L., Zuber, A., Dénarié J., Dixon, R. A., May, G. D., Schwartz, D. C., Rogers, J., Quétier, F., Town, C. D., and Roe, B. A. 2011. The Medicago genome provides insight into the evolution of rhizobial symbioses. Nature 480:520-524.

Zhu, H., Choi, H. K., Cook, D. R., and Shoemaker, R. C. 2005. Bridging model and crop legumes through comparative genomics. Plant Physiol. 137:1189-1196.

\section{AUTHOR-RECOMMENDED INTERNET RESOURCES}

Australian Plant Genetic Resources Information Services database: www2.dpi.qld.gov.au/extra/asp/AusPGRIS

Centro International de Agricultura Tropical homepage: isa.ciat.cgiar.org/urg/main.do

CIRAD ESTtik pipeline: esttik.cirad.fr

Index to Plant Chromosome Numbers database: www.tropicos.org/Project/IPCN

International Legume Database \& Information Services dtabase: www.ildis.org

International Rice Research Institute homepage: www.irri.org

Kew Gardens Seed Bank: data.kew.org/seedlist/index.html

Primer3 program: frodo.wi.mit.edu/primer3

Tropicos, a website gathering nomenclatural, bibliographic, and data on tropical species: www.tropicos.org

United State Department of Agriculture website: www.ars-grin.gov 